\title{
Mercury in leaf litter in typical suburban and urban broadleaf forests in China
}

\author{
Zhenchuan Niu, Xiaoshan Zhang, Zhangwei Wang*, Zhijia Ci \\ Research Center for Eco-Environmental Sciences, Chinese Academy of Sciences, Beijing 100085, China. E-mail: caoren03@yahoo.com.cn
}

Received 30 January 2011; revised 11 April 2011; accepted 14 April 2011

\begin{abstract}
To study the role of leaf litter in the mercury $(\mathrm{Hg})$ cycle in suburban broadleaf forests and the distribution of $\mathrm{Hg}$ in urban forests, we collected leaf litter and soil from suburban evergreen and deciduous broadleaf forests and from urban forests in Beijing. The $\mathrm{Hg}$ concentrations in leaf litter from the suburban forests varied from 8.3 to $205.0 \mathrm{ng} / \mathrm{g}$, with an average (avg) of $(49.7 \pm 36.9) \mathrm{ng} / \mathrm{g}$. The average $\mathrm{Hg}$ concentration in evergreen broadleaf forest leaf litter $(50.8 \pm 39.4) \mathrm{ng} / \mathrm{g}$ was higher than that in deciduous broadleaf forest leaf litter $(25.8 \pm 10.1) \mathrm{ng} / \mathrm{g}$. The estimated $\mathrm{Hg}$ fluxes of leaf litter in suburban evergreen and deciduous broadleaf forests were 179.0 and $83.7 \mathrm{mg} /($ ha $\cdot y r)$, respectively. The $\mathrm{Hg}$ concentration in organic horizons (O horizons) $((263.1 \pm 237.2) \mathrm{ng} / \mathrm{g}$ ) was higher than that in eluvial horizons (A horizons) $((83.9 \pm 52.0) \mathrm{ng} / \mathrm{g})$. These results indicated that leaf litterfall plays an important role in transporting atmospheric mercury to soil in suburban forests. For urban forests in Beijing, the $\mathrm{Hg}$ concentrations in leaf litter ranged from 8.8-119.0 (avg $28.1 \pm 16.6$ ) $\mathrm{ng} / \mathrm{g}$, with higher concentrations at urban sites than at suburban sites for each tree. The Hg concentrations in surface soil in Beijing were 32.0-25300.0 ng/g and increased from suburban sites to urban sites, with the highest value from Jingshan (JS) Park at the centre of Beijing. Therefore, the distribution of $\mathrm{Hg}$ in Beijing urban forests appeared to be strongly influenced by anthropogenic activities.
\end{abstract}

Key words: mercury; broadleaf forests; leaf litter; soil; flux

DOI: $10.1016 /$ S1001-0742(10)60669-9

Citation: Niu Z C, Zhang X S, Wang Z W, Ci Z J, 2011. Mercury in leaf litter in the typical suburban and urban broadleaf forests, China. 23(12): 2042-2048

\section{Introduction}

Mercury $(\mathrm{Hg})$ is a global contaminant, likely spreading across the world through long-range atmospheric transport. Every year, thousands of tons of $\mathrm{Hg}$ are emitted into the atmosphere from natural and anthropogenic sources. Atmospheric $\mathrm{Hg}$ may be deposited into a forest canopy in gaseous and aerosol forms, and deposited $\mathrm{Hg}^{0}$ and reactive gaseous $\mathrm{Hg}$ (RGM) may be taken up by leaf stomata (Lindberg et al., 1979). Current research has identified that the strength of known atmospheric $\mathrm{Hg}$ sources is greater than previous estimations (Gustin et al., 2000; Engle et al., 2001; Pirroni et al., 2001), and vegetation is regarded as the missing sink in global $\mathrm{Hg}$ mass balance (Gustin et al., 2008). It is estimated that aboveground vegetation sequesters over 1000 tons $\mathrm{Hg}$ from the atmosphere every year (Obrist, 2007).

Litterfall is a major component of both energy flow and nutrient recycling in forest ecosystems. Global flux of $\mathrm{Hg}$ by way of litterfall is estimated to be 2400-6000 tons/yr, and is suggested to be the largest $\mathrm{Hg}$ flux to forest floors (Lindberg et al., 2004). Leaves account for 50\%-84\% of litterfall biomass (Silva-Filho et al., 2006) and their $\mathrm{Hg}$

\footnotetext{
* Corresponding authors. E-mail: wangzhw@ rcees.ac.cn
}

concentrations are the highest among litterfall components (Nóvoa-Muñoz et al., 2008). Consequently, leaves are a significant determinant factor of litterfall flux and studies about the role of leaf litter on the $\mathrm{Hg}$ cycle in forests are necessary. Researchers from countries such as the United States of America (Rea et al., 1996, 2002; Sheehan et al., 2006), Canada (St Louis et al., 2001; Graydon et al., 2008), Sweden (Iverfeldt, 1991; Munthe et al., 1995), Spain (Nóvoa-Muñoz et al., 2008), and Brazil (Roulet et al., 1999; Fostier et al., 2003; Silva-Filho et al., 2006), have studied the role of litterfall in transferring atmospheric $\mathrm{Hg}$ to soils in boreal, temperate, and tropical forests. In China, Wang et al. (2009) and Fu et al. (2010) reported the $\mathrm{Hg}$ concentrations and fluxes of litterfall in southwestern subtropical forests. However, regional and even nationwide investigations on $\mathrm{Hg}$ concentrations in leaf litter and soil in Chinese forests have not been conducted.

Mercury in surface soil is an indicator of soil quality, while $\mathrm{Hg}$ in foliages at urban sites is an indicator of air quality (Barghigiani et al., 1991; Zhang et al., 2006). In addition, mercury in surface soil and foliage is a potential source of atmospheric and soil $\mathrm{Hg}$, respectively (Lindberg et al., 2004). During the past three decades, Beijing has been undergoing fast economic development and urban construction. Soil and atmospheric $\mathrm{Hg}$ pollution has been 
studied in some urban areas (Liu et al., 2002; Wang et al., 2006; Zhang et al., 2006; Chen et al., 2010). It is also necessary, however, to study the distribution of $\mathrm{Hg}$ in leaf litter and soil in urban forests. Therefore, the goals of this study were to: (1) investigate the $\mathrm{Hg}$ concentrations in leaf litter and soil of evergreen and deciduous broadleaf forests in the suburban mountains of Chinese cities; and (2) investigate $\mathrm{Hg}$ distribution in leaf litter and surface soil within different forms of land use in Beijing urban forests.

\section{Materials and methods}

\subsection{Site location}

The study sites were divided into suburban and urban forests according to the influential extent of human activities. Suburban forests included both evergreen and deciduous broadleaf forests. Twenty-two sites were located at the suburban mountainous area of 19 cities in 8 provinces in China. Urban forest sites in Beijing were situated in the vicinity of landfills (outside the 5th Ring Road), universities, parks and streets, which contained 45 sites for each type of land use. The abbreviations and locations of these sites are presented in Table 1 and Fig. 1.

\subsection{Sample collection}

Samples of leaf litter and soils in eluvial horizons (A horizons) were collected from every suburban forest, and samples in organic horizons (O horizons) were also collected from some forests. The main tree species in the suburban evergreen broadleaf forests include Castanopsis carlesii (Hemsl.) Hayata, Schima superba Gardn. et Champ, Castanopsis fargesii Franch, Cyclobalanopsis myrsinaefolia (B1.) Oerst, Lithocarpus glaber (Thunb.) Nakai, Cinnamomum camphora (Linn.) Presl and Tsoongiodendron odorum Chun. In deciduous broadleaf forests, the main tree species were Fraxinus mandschurica Rupr.,
Populus davidiana Dode, Betula platyphylla Suk., Ulmus pumila L., Quercus liaotungensis Koidz. and Acer truncatum Bunge.

In Beijing urban forests, broadleaf trees Sophora japonica L., Populus tomentosa Carr., Ginkgo biloba L. were selected. For comparison, coniferous trees Sabina chinensis L. and Pinus tabulaeformis Carr. were also selected.

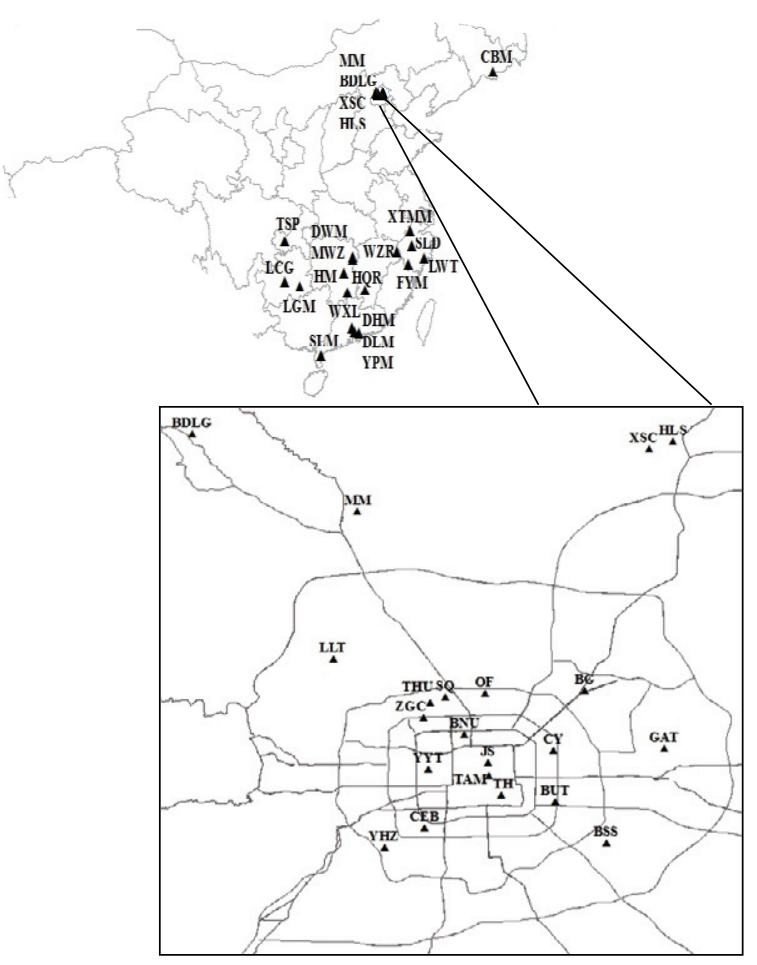

Fig. 1 Location of suburban forest sites in China and urban forest sites in Beijing. Abbreviations of sites are presented in Table 1.

Table 1 Abbreviations of suburban forest sites in China and urban forest sites in Beijing

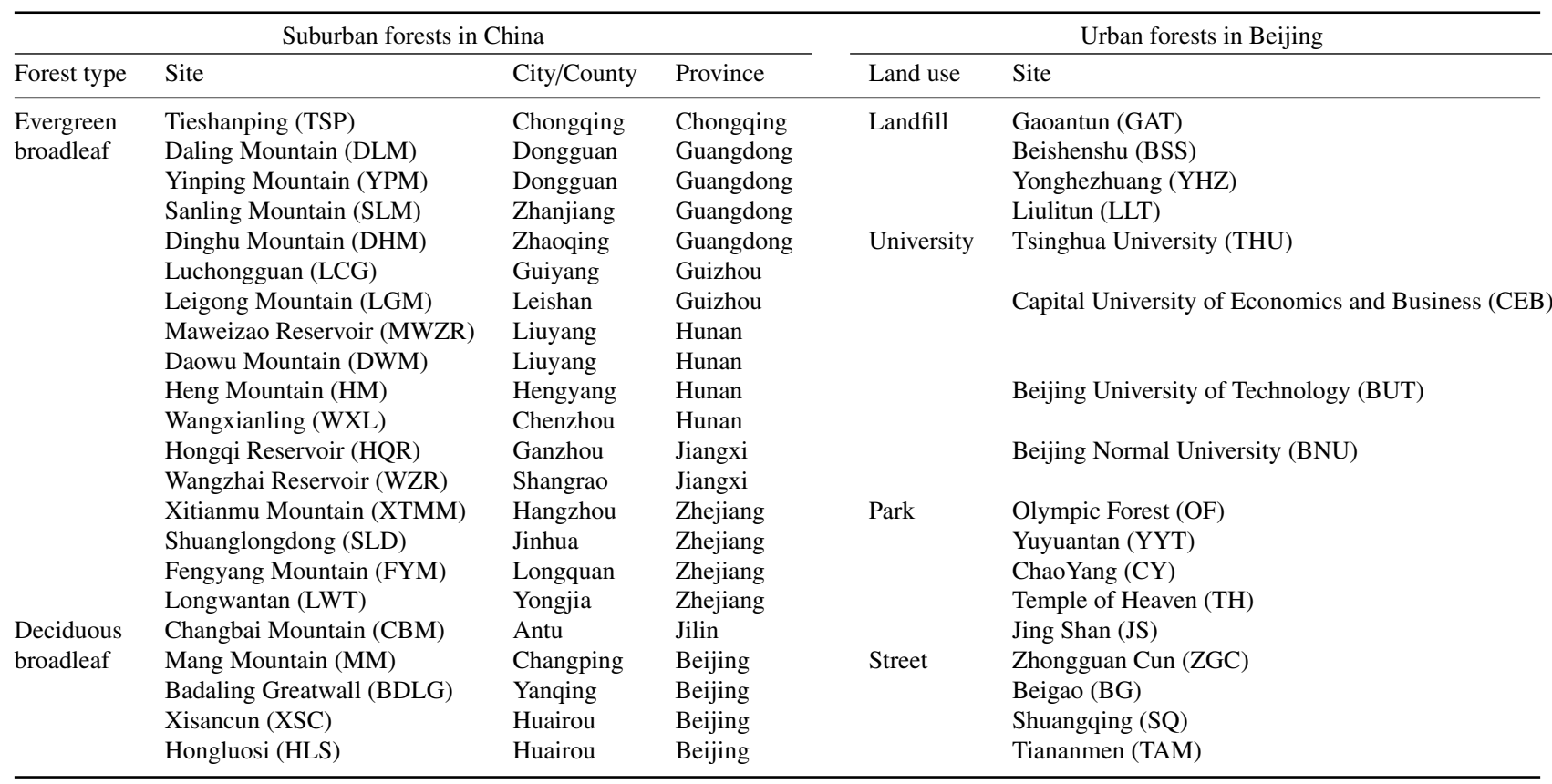


Leaf samples were collected from five parallel individuals at each site. Surface soil $(1-2 \mathrm{~cm})$ was collected at each site from all four directions (north, south, west, and east) with a stainless steel shovel, and then was mixed together as the sample of one site.

Samples of leaf litter and soil were put in plastic ziplock bags and transported to the laboratory immediately. Leaf litter was first rinsed by tap water, and then rinsed by ultra pure deionized water in laboratory. Leaf litter samples were dried at $55^{\circ} \mathrm{C}$, ground, and then stored at $-4^{\circ} \mathrm{C}$ for analysis. Soil samples were air-dried, ground, sieved and then stored at $-4^{\circ} \mathrm{C}$ for analysis.

\subsection{Sample analysis}

The $\mathrm{Hg}$ concentrations in leaf litter and soil samples were measured by an RA- $915^{+} \mathrm{Hg}$ analyzer attached with PYRO-91 thermal decomposition accessory (Lumex Inc., Russia). The samples were thermally decomposed in an atomizer chamber at $750^{\circ} \mathrm{C}$ with aided catalytic action, and then the RA- $915^{+}$analyzer detected the $\mathrm{Hg}^{0}$. Each sample was analyzed three times and then averaged. In this study, instrument calibration curves covering the appropriate concentrations were confirmed by soil standards (GBW07404, $590 \mathrm{ng} / \mathrm{g}$ ) and peach foliage standards (GBW08501, 40 $\mathrm{ng} / \mathrm{g}$ ), and control standard samples were checked every ten samples. The instrument detection limit was $5 \mathrm{pg}$ for solid samples. The precisions, obtained from ten replicated determinations of standards, were $3.47 \%$ for soil and $2.83 \%$ for peach foliage.

\subsection{Data analysis}

Analysis of variance (ANOVA) was performed using SPSS 11.5 for windows. Data were presented as mean and standard deviation, and statistical significance was considered at $p<0.05$.

\section{Results and discussion}

\subsection{Hg concentrations in leaf litter and soil in Chinese suburban forests}

The average $\mathrm{Hg}$ concentration in evergreen broadleaf forest leaf litter $((50.8 \pm 39.4) \mathrm{ng} / \mathrm{g})$ was about two times the concentration in deciduous broadleaf forest litter $((25.8 \pm 10.1) \mathrm{ng} / \mathrm{g})$. This may be the result of a longer growth period for evergreen plants, with previous studies indicating that $\mathrm{Hg}$ concentrations in foliage increased with time (Ericksen et al., 2003; Millhollen et al., 2006). The $\mathrm{Hg}$ concentration at SLD $((119.9 \pm 30.3) \mathrm{ng} / \mathrm{g})$ was the highest among all the sites, with LCG $((91.8 \pm 78.2) \mathrm{ng} / \mathrm{g})$ presenting the second highest concentration (Table 2). In this study, the $\mathrm{Hg}$ concentrations in leaf litter in Chinese suburban forests were 8.3-205.0 (avg $49.7 \pm 36.9) \mathrm{ng} / \mathrm{g}$, within the range of $8-250 \mathrm{ng} / \mathrm{g}$ reported in the United States of America, Canada, Brazil, Sweden, and French Guiana (Table 3), but lower than those reported in Chinese southwest forests (Wang et al., 2009).

The soil $\mathrm{Hg}$ concentrations in A horizons and $\mathrm{O}$ horizons in Chinese suburban forests were 23.7-181.7 (avg $83.9 \pm 52.0) \mathrm{ng} / \mathrm{g}$ and 95.3-860.7 (avg 263.1 \pm 237.2) $\mathrm{ng} / \mathrm{g}$, respectively. Most soil $\mathrm{Hg}$ concentrations in the A horizons were lower than the Natural Standard Value for Soil Environment Quality I of $\mathrm{Hg}$ (150 ng/g, GB156181995) and concentrations in 11 sites were lower than the background soil $\mathrm{Hg}$ value $(65 \mathrm{ng} / \mathrm{g}$ ) in China (SEPAC, 1990), which indicated that most A horizon soils in the suburban forests were not polluted by $\mathrm{Hg}$. The concentrations in the O horizons were 1.2-19.1 times those in the A horizons. Nóvoa-Muñoz et al. (2008) also reported $\mathrm{Hg}$ concentrations in $\mathrm{O}$ horizons (216.9-248.2 ng/g) higher than those in A horizons (108.1-195.0 ng/g) in Spain. Wang et al. (2009) reported that soil $\mathrm{Hg}$ concentrations decreased with soil depth in Chinese southwest forests. Larssen et al. (2008) reported the organic horizon and the

Table $2 \mathrm{Hg}$ concentrations in leaf litter and soil at each suburban forest site

\begin{tabular}{|c|c|c|c|c|c|c|c|}
\hline \multicolumn{4}{|c|}{ Evergreen broadleaf forest } & \multicolumn{4}{|c|}{ Deciduous broadleaf forest } \\
\hline \multirow[t]{2}{*}{ Site } & \multirow{2}{*}{$\begin{array}{l}\text { Leaf litter }(\mathrm{ng} / \mathrm{g}) \\
\text { mean } \pm \mathrm{SD}(\text { range })\end{array}$} & \multicolumn{2}{|c|}{ Soil (ng/g) } & \multirow[t]{2}{*}{ Site } & \multirow{2}{*}{$\begin{array}{l}\text { Leaf litter }(\mathrm{ng} / \mathrm{g}) \\
\text { mean } \pm \mathrm{SD}(\text { range })\end{array}$} & \multicolumn{2}{|c|}{ Soil (ng/g) } \\
\hline & & O horizon & A horizon & & & O horizon & A horizon \\
\hline DLM & $22.0 \pm 12.7(13.0-31.0)$ & - & $31.0 \pm 4.2$ & CBM & $27.0 \pm 8.8(21.5-40.0)$ & $860.7 \pm 24.2$ & $45.0 \pm 1.4$ \\
\hline DWM & $45.5 \pm 18.3(23.0-68.0)$ & $221.0 \pm 7.0$ & $181.7 \pm 9.0$ & MM & $21.3 \pm 8.6(13.3-33.0)$ & - & $63.0 \pm 1.4$ \\
\hline DHM & $46.6 \pm 10.8(34.0-64.0)$ & - & $170.5 \pm 2.1$ & BDLG & $31.7 \pm 25.0(14.0-49.3)$ & - & $40.0 \pm 2.1$ \\
\hline FYM & $30.7 \pm 7.5(22.0-35.0)$ & $99.3 \pm 5.5$ & $66.5 \pm 3.5$ & XSC & $27.4 \pm 9.0(15.0-36.3)$ & - & $32.0 \pm 1.4$ \\
\hline HM & $68.8 \pm 41.4(32.0-125.0)$ & $130.7 \pm 0.6$ & $95.7 \pm 3.1$ & HLS & $25.0 \pm 9.3(15.7-39.0)$ & - & $37.3 \pm 2.1$ \\
\hline HQR & $25.0 \pm 10.4(18.0-37.0)$ & - & $58.5 \pm 3.5$ & & & & \\
\hline LGM & $69.6 \pm 55.5(25.0-187.5)$ & $323.3 \pm 17.6$ & $177.7 \pm 11.7$ & & & & \\
\hline LWT & $57.4 \pm 15.6(31.0-69.0)$ & - & $61.0 \pm 2.6$ & & & & \\
\hline LCG & $91.8 \pm 78.2(34.0-205.0)$ & $283.3 \pm 7.8$ & $121.3 \pm 8.4$ & & & & \\
\hline MWZR & $57.0 \pm 13.8(41.0-69.0)$ & $95.3 \pm 1.5$ & $23.7 \pm 1.5$ & & & & \\
\hline SLM & $31.5 \pm 21.9(16.0-47.0)$ & - & $39.5 \pm 4.9$ & & & & \\
\hline SLD & $119.9 \pm 30.3(91.5-147.0)$ & - & $71.5 \pm 2.1$ & & & & \\
\hline TSP & $41.3 \pm 12.4(29.0-57.0)$ & - & $79.0 \pm 1.4$ & & & & \\
\hline WXL & $67.5 \pm 21.1(41.0-86.0)$ & $182.3 \pm 4.2$ & $155.0 \pm 2.0$ & & & & \\
\hline WZR & $21.1 \pm 13.1(8.3-47.0)$ & - & $150.5 \pm 0.7$ & & & & \\
\hline XTMM & $43.0 \pm 49.2(9.7-151.0)$ & $172.3 \pm 3.2$ & $94.3 \pm 0.6$ & & & & \\
\hline YPM & $16.9 \pm 5.9(9.4-22.0)$ & - & $51.5 \pm 2.1$ & & & & \\
\hline
\end{tabular}

- indicates no samples. 
Table 3 Comparison of $\mathrm{Hg}$ concentrations and fluxes in different countries

\begin{tabular}{|c|c|c|c|}
\hline Country & Hg concentration $(\mathrm{ng} / \mathrm{g})$ & $\mathrm{Hg}$ flux (mg/(ha·yr)) & Reference \\
\hline \multirow[t]{2}{*}{ China } & leaf litter: $8.3-205,49.7 \pm 36.9$ & leaf litter: $179.0,83.7$ & This study \\
\hline & litter: $104.8 \pm 18.6-135.1 \pm 31.7$ & & Wang et al., 2009 \\
\hline \multirow[t]{3}{*}{ America } & green foliage: $34.2 \pm 7.2$, litter: $53.2 \pm 11.4$ & litter: 130 & Rea et al., 1996 \\
\hline & litter: $36 \pm 8$ & litter: $158 \pm 19,114 \pm 28$ & Rea et al., 2002 \\
\hline & litter: $31.6-58.8$ & litter: 100,101 & Sheehan et al., 2006 \\
\hline \multirow[t]{2}{*}{ Canada } & litter: $33-79$ & litter: $110-220$ & St. Louis et al., 2001 \\
\hline & litter: $28.9-69.2$ & litter: $86-105$ & Graydon et al., 2008 \\
\hline \multirow[t]{2}{*}{ Sweden } & litter: 97.4-140.6, 20-80 & litter: 250 & Iverfeldt, 1991 \\
\hline & litter: $33-140$ & & Munthe et al., 1995 \\
\hline \multirow[t]{3}{*}{ Brazil } & green foliage: $40-152$, leaf litter: $56-140$ & & Roulet et al., 1999 \\
\hline & litter: $72-100$ & & Fostier et al., 2003 \\
\hline & litter: $20-244$ & litter: 1220 & Silva-Filho et al., 2006 \\
\hline French Guiana & leaves: $32.4-114$ & litter: $450 \pm 100$ & Mélières et al., 2003 \\
\hline
\end{tabular}

illuviation horizon have clearly higher $\mathrm{Hg}$ concentrations than do other horizons in mineral soil in Norway. However, Roulet et al. (1999) reported that the rapid turnover of organic matter at the surface of tropical soil in the Brazilian Amazonian ecosystems limited the accumulation of $\mathrm{Hg}$ in the organic horizon, which was much lower than that in the underlying mineral horizons. The present study showed that the $\mathrm{Hg}$ concentration in the $\mathrm{O}$ horizon at CBM (860.7 $\mathrm{ng} / \mathrm{g}$ ) was much higher than that in the other evergreen broadleaf forests. Slow decomposition of litter due to low temperatures at CBM led the $\mathrm{Hg}$ in litterfall accumulated in the O horizon. Guo et al. (2006) reported that $95 \%$ of leaf and twig decomposition takes about 4.5-8.0 and 7.829.3 years at CBM, respectively.

\subsection{Distribution of $\mathrm{Hg}$ in leaf litter and surface soil in Beijing forests}

The $\mathrm{Hg}$ concentrations in leaf litter in Beijing were $28.1 \pm 16.6(8.8-119.0) \mathrm{ng} / \mathrm{g}$, nearly the same as those in suburban deciduous broadleaf forests $((25.8 \pm 10.1)$ $\mathrm{ng} / \mathrm{g})$, but lower than those in suburban evergreen broadleaf forests $((50.8 \pm 39.4) \mathrm{ng} / \mathrm{g})$. This may ascribe that the tree species in Beijing are mainly deciduous, and their leaf growth periods are shorter than those of evergreen plants. The Hg concentrations in leaf litter did not correlate significantly with soil $\mathrm{Hg}$ concentrations for each species $(p>0.05)$, so $\mathrm{Hg}$ in leaves may originate mainly from the atmosphere. For S. japonica, the $\mathrm{Hg}$ concentrations at the streets, gardens, and universities were higher than those near landfills and suburban areas. The same results were found for P. tomentosa, G. biloba, S. hinensis, and P. tabulaeformis (Table 4). De Temmerman et al. (2007, 2009) showed that foliar $\mathrm{Hg}$ concentrations linearly correlate with atmospheric $\mathrm{Hg}$ concentrations, while Liu et al. (2002) showed that atmospheric $\mathrm{Hg}$ concentrations at the centre of Beijing (7.9-34.9 ng/ $\left.\mathrm{m}^{3}\right)$ are higher than those in suburban $\left(5.3-12.4 \mathrm{ng} / \mathrm{m}^{3}\right)$ and rural $\left(2.5-5 \mathrm{ng} / \mathrm{m}^{3}\right)$ areas. Therefore, the difference of $\mathrm{Hg}$ concentrations in leaf litter for each species might roughly indicate the atmospheric $\mathrm{Hg}$ pollution among different land use forms.

At most sites, the $\mathrm{Hg}$ concentrations in S. japonica, $P$. tomentosa and $G$. biloba were higher than those in $S$. chinensis and P. tabulaeformis. It appeared, therefore, that the leaves of broadleaf trees accumulated more $\mathrm{Hg}$ than those of coniferous trees. This may result from the fewer stoma in the leaves of coniferous trees.

The $\mathrm{Hg}$ concentrations in surface soil in Beijing varied from 32.0 to $25300.0 \mathrm{ng} / \mathrm{g}$, with a median of $129.5 \mathrm{ng} / \mathrm{g}$ and an average of $1502.1 \mathrm{ng} / \mathrm{g}$. Li et al. (2010) reported that the $\mathrm{Hg}$ concentration in Beijing topsoil ranges from 12.1

Table $4 \mathrm{Hg}$ concentrations in surface soils and leaf litter at different land use types in Beijing

\begin{tabular}{|c|c|c|c|c|c|c|c|c|c|c|c|c|c|}
\hline \multirow[t]{2}{*}{ Type } & \multirow[t]{2}{*}{ Site } & \multirow[t]{2}{*}{ Soil (ng/g) } & \multirow{2}{*}{$\begin{array}{l}\text { Avg } \\
(\mathrm{ng} / \mathrm{g})\end{array}$} & \multicolumn{10}{|c|}{ Leaf litter (ng/g) } \\
\hline & & & & S. japonica & Avg & P. tomentos & Avg & G. biloba & Avg & S. chinensis & Avg & P. tabulaeformis & Avg \\
\hline \multirow[t]{3}{*}{ Suburban } & MM & $63.0 \pm 0.4$ & \multirow[t]{3}{*}{44.1} & $33.0 \pm 1.4$ & \multirow[t]{3}{*}{28.3} & $22.0 \pm 1.4$ & \multirow[t]{3}{*}{29.2} & - & \multirow[t]{3}{*}{-} & $13.3 \pm 0.5$ & \multirow[t]{3}{*}{14.7} & $16.7 \pm 0.5$ & \multirow[t]{3}{*}{21.4} \\
\hline & $\mathrm{XSC}$ & $32.0 \pm 1.4$ & & $30.7 \pm 0.5$ & & $36.3 \pm 0.9$ & & - & & $15.0 \pm 0.8$ & & $27.7 \pm 0.9$ & \\
\hline & HLS & $37.3 \pm 1.7$ & & $21.3 \pm 2.1$ & & $29.3 \pm 2.1$ & & - & & $15.7 \pm 0.5$ & & $19.7 \pm 0.5$ & \\
\hline \multirow[t]{4}{*}{ Landfill } & GAT & $89.0 \pm 5.4$ & \multirow[t]{4}{*}{99.4} & $28.7 \pm 0.5$ & \multirow[t]{4}{*}{33.1} & $37.0 \pm 0.0$ & \multirow[t]{4}{*}{28.0} & $11.7 \pm 1.2$ & \multirow[t]{4}{*}{12.6} & $16.3 \pm 0.9$ & \multirow[t]{4}{*}{14.8} & $13.7 \pm 1.2$ & \multirow[t]{4}{*}{13.8} \\
\hline & LLT & $94.3 \pm 17.6$ & & $69.0 \pm 1.6$ & & $26.0 \pm 1.4$ & & - & & $23.7 \pm 1.2$ & & $21.0 \pm 0.8$ & \\
\hline & BSS & $101.0 \pm 12.6$ & & $22.3 \pm 0.5$ & & $22.0 \pm 0.8$ & & $13.7 \pm 0.9$ & & $8.8 \pm 0.8$ & & $9.4 \pm 0.4$ & \\
\hline & YHZ & $113.3 \pm 11.8$ & & $12.3 \pm 0.5$ & & $27.0 \pm 1.6$ & & $12.3 \pm 0.9$ & & $10.3 \pm 0.5$ & & $11.0 \pm 0.8$ & \\
\hline \multirow[t]{4}{*}{ University } & THU & $255.0 \pm 49.3$ & \multirow[t]{4}{*}{384.6} & $67.0 \pm 2.2$ & \multirow[t]{4}{*}{44.8} & $42.3 \pm 1.7$ & \multirow[t]{4}{*}{36.8} & $23.7 \pm 1.2$ & \multirow[t]{4}{*}{18.8} & $21.0 \pm 0.8$ & \multirow[t]{4}{*}{17.3} & $57.3 \pm 0.5$ & \multirow[t]{4}{*}{29.6} \\
\hline & CEB & $308.7 \pm 30.0$ & & $40.0 \pm 2.2$ & & $35.0 \pm 0.8$ & & $15.3 \pm 0.9$ & & $15.0 \pm 0.8$ & & $19.0 \pm 0.8$ & \\
\hline & BUT & $442 \pm 55.7$ & & $32.0 \pm 0.0$ & & $36.0 \pm 0.8$ & & $15.7 \pm 0.5$ & & $17.3 \pm 0.5$ & & $19.0 \pm 0.0$ & \\
\hline & $\mathrm{BNU}$ & $532.7 \pm 49.3$ & & $40.0 \pm 0.0$ & & $33.7 \pm 0.5$ & & $20.7 \pm 0.5$ & & $15.7 \pm 0.5$ & & $23.0 \pm 0.8$ & \\
\hline \multirow[t]{5}{*}{ Park } & $\mathrm{OF}$ & $117.0 \pm 16.3$ & \multirow[t]{5}{*}{5420.2} & $49.3 \pm 0.9$ & \multirow[t]{5}{*}{45.3} & $28.7 \pm 1.2$ & \multirow[t]{5}{*}{37.6} & $11.3 \pm 0.5$ & \multirow[t]{5}{*}{25.5} & $13.0 \pm 0.8$ & 16.7 & $52.3 \pm 2.1$ & 28.9 \\
\hline & YYT & $137.3 \pm 8.8$ & & $39.0 \pm 0.0$ & & $44.0 \pm 0.0$ & & $27.7 \pm 1.2$ & & $13.0 \pm 0.8$ & & $21.0 \pm 1.4$ & \\
\hline & $\mathrm{CY}$ & $250.0 \pm 43.3$ & & $37.0 \pm 0.8$ & & $47.7 \pm 1.2$ & & $23.3 \pm 1.2$ & & $12.0 \pm 0.8$ & & $16.7 \pm 0.9$ & \\
\hline & $\mathrm{TH}$ & $1296.7 \pm 9.4$ & & $41.0 \pm 0.8$ & & $33.0 \pm 0.8$ & & $27.7 \pm 1.7$ & & $20.3 \pm 0.5$ & & $22.0 \pm 0.8$ & \\
\hline & JS & $25300.0 \pm 408.2$ & & $60.0 \pm 0.0$ & & $34.7 \pm 0.5$ & & $37.3 \pm 2.6$ & & $25.0 \pm 1.4$ & & $32.3 \pm 2.1$ & \\
\hline Street & ZGC & $81.3 \pm 10.7$ & 217.9 & $42.3 \pm 1.2$ & 46.3 & $32.3 \pm 1.2$ & 34.0 & $12.3 \pm 0.5$ & 18.7 & $13.3 \pm 0.9$ & 20.8 & $20.0 \pm 1.4$ & 45.0 \\
\hline & BG & $121.7 \pm 10.7$ & & $39.3 \pm 0.5$ & & $30.0 \pm 0.8$ & & $21.3 \pm 1.2$ & & $23.0 \pm 0.0$ & & $21.3 \pm 0.5$ & \\
\hline & SQ & $262.0 \pm 15.1$ & & $75.0 \pm 1.6$ & & $38.0 \pm 1.6$ & & $26.7 \pm 0.5$ & & $34.0 \pm 0.8$ & & $119.0 \pm 0.8$ & \\
\hline & TAM & $406.7 \pm 27.4$ & & $28.3 \pm 1.2$ & & $35.7 \pm 0.5$ & & $14.3 \pm 0.5$ & & $12.7 \pm 0.5$ & & $19.7 \pm 0.5$ & \\
\hline
\end{tabular}


to $8487 \mathrm{ng} / \mathrm{g}$, lower than the maximal value of $25300 \mathrm{ng} / \mathrm{g}$ in this study, and the median $\mathrm{Hg}$ concentration is 471.3 $\mathrm{ng} / \mathrm{g}$, much higher than the median concentration of 129.5 $\mathrm{ng} / \mathrm{g}$ in this study. Most $\mathrm{Hg}$ concentrations were lower than the Natural Standard Value for Soil Environment Quality II of $\mathrm{Hg}$ (1000 ng/g, GB15618-1995), except the soil $\mathrm{Hg}$ concentrations in the TH and JS Parks. The median $\mathrm{Hg}$ concentration of $129.5 \mathrm{ng} / \mathrm{g}$ in surface soil was $61.9 \%$ higher than the reported background concentrations in Beijing ( $80 \mathrm{ng} / \mathrm{g}$, Environmental Monitoring of China, 1994).

The $\mathrm{Hg}$ concentrations in surface soil increased from suburban sites to urban sites, with the highest value in the JS Park at the centre of Beijing. Soil $\mathrm{Hg}$ concentrations with different types of land use followed the sequence: classical park $(\mathrm{TH}, \mathrm{JS})>$ university $>$ street $>$ vicinity of landfill $>$ suburban. These results indicated that the $\mathrm{Hg}$ distribution in Beijing was influenced by anthropogenic activities. $\mathrm{Li}$ et al. (2010) reported that the median $\mathrm{Hg}$ concentration in different regions occurred in the following order: urban center soil > suburban soil > rural soil, and thought that the regional $\mathrm{Hg}$ distribution was closely related to anthropogenic and industrial activities. The $\mathrm{Hg}$ concentrations in classical parks were relatively higher than those in other land use forms, and also higher than those in parks in many other countries (Table 5). This may relate to the use of gold amalgamation or cinnabar as paint in classical parks. Chen et al. (2010) also reported soil $\mathrm{Hg}$ concentrations in three classical parks (Beihai, Zhongshan, $\mathrm{TH}$ ) in Beijing as 9400, 6500 and $4200 \mathrm{ng} / \mathrm{g}$, respectively. In this study, the $\mathrm{Hg}$ concentrations in universities were relatively high, as reported by Chen et al. (2010) who inferred that the use of $\mathrm{Hg}$ in medical and scientific apparatuses in cultural and educational areas was the main reason for this concentration. However, the $\mathrm{Hg}$ concentrations at the streets (except TAM) were not actually high. Chen et al. (2010) suggested that traffic was not a main source for $\mathrm{Hg}$ in roadside areas. The low $\mathrm{Hg}$ concentrations in the vicinity of landfills may ascribe to location, as all landfills were located outside the 5th Ring Road, far from urban areas.

\subsection{Estimations of $\mathrm{Hg}$ fluxes of leaf litter in evergreen and deciduous broadleaf forests}

In this study, the Hg flux of leaf litterfall was estimated by the biomass of leaf litter multiplied by the $\mathrm{Hg}$ concentration in leaf litter (Rea et al., 1996; Sheehan et al., 2006; Silva-Filho et al., 2006; Wang et al., 2009). Because of a lack of information on biomass of leaf litterfall in urban forests, we only estimated the fluxes in suburban evergreen and deciduous broadleaf forests. We averaged the data on biomass of leaf litter in evergreen and deciduous broadleaf forests reported by others, and obtained $\mathrm{Hg}$ fluxes of 179.0 and $83.7 \mathrm{mg} /($ ha·yr), respectively (Table 6). These fluxes were nearly at the same level of those reported in America, Canada and Sweden (Table 3), but lower than those reported in French Guiana (Mélières et al., 2003), and much lower than those reported in the Brazilian Amazon (Silva-Filho et al., 2006) (Table 3). The extremely high values at the two sites may be ascribed to the huge biomass of litterfall in tropical rainforests. The $\mathrm{Hg}$ fluxes of leaf litterfall in deciduous and evergreen broadleaf forests were nearly the same with a wet deposition flux of 84 $\mathrm{mg} /(\mathrm{ha} \cdot \mathrm{yr}$ ) and a dry deposition flux of $165 \mathrm{mg} /(\mathrm{ha} \cdot \mathrm{yr})$ at CBM (Wan et al., 2009), respectively. Therefore, the input

Table 5 Soil $\mathrm{Hg}$ concentrations in urban forests at different countries

\begin{tabular}{|c|c|c|}
\hline Site & $\mathrm{Hg}$ concentration $(\mathrm{ng} / \mathrm{g})$ & Reference \\
\hline Beijing, China & 32.0-25300, classical park: $1297-25300$ & This study \\
\hline Beijing, China & $16-966(278)$ & Zhang et al., 2006 \\
\hline Beijing, China & 22-9400, classical park: 1100-9400 & Chen et al., 2010 \\
\hline Aveiro, Portugal & Park: $32-130(59)$ & Rodrigues et al., 2006 \\
\hline Glasgow, England & Park: $310-5200(1600)$ & Rodrigues et al., 2006 \\
\hline Ljubljana, Serbia & Park: $150-860(410)$ & Rodrigues et al., 2006 \\
\hline Sevilla, Spain & Park: 110-1300 (420) & Rodrigues et al., 2006 \\
\hline Torino, Italy & Park: 210-900 (480) & Rodrigues et al., 2006 \\
\hline Uppsala, Sweden & Park: 15-1200 (350) & Rodrigues et al., 2006 \\
\hline Palermo, Italy & Park and greenland: 40-56000, media 1850 & Manta et al., 2002 \\
\hline
\end{tabular}

Table $6 \mathrm{Hg}$ fluxes of leaf litter in evergreen and deciduous broadleaf forests

\begin{tabular}{|c|c|c|c|c|c|}
\hline $\begin{array}{l}\text { Broadleaf } \\
\text { forest type }\end{array}$ & $\begin{array}{l}\text { Biomass of leaf litter reported } \\
\text { in China }(\mathrm{kg} /(\mathrm{ha} \cdot \mathrm{yr}))\end{array}$ & $\begin{array}{l}\text { Average biomass } \\
(\mathrm{kg} /(\text { ha } \cdot \mathrm{yr}))\end{array}$ & $\begin{array}{l}\text { Average } \mathrm{Hg} \\
\text { concentrations (ng/g) }\end{array}$ & $\begin{array}{l}\text { Hg flux } \\
(\mathrm{mg} /(\text { ha } \cdot \mathrm{yr}))\end{array}$ & Reference \\
\hline Evergreen & $\begin{array}{l}3764 \\
2969.1 \\
3033,3499 \\
4260 \\
1876.18,3970.88 \\
3964 \\
1788.07 \\
2350 \\
4031.4,6143.2,4155.4\end{array}$ & 3523.3 & 50.8 & 179.0 & $\begin{array}{l}\text { Hou et al., } 1998 \\
\text { Lin et al., } 1999 \\
\text { Yang et al., } 2001 \\
\text { Guan et al., } 2004 \\
\text { Chen et al., } 2006 \\
\text { Wu, 2006 } \\
\text { Fan et al., } 2007 \\
\text { Wei et al., } 2009 \\
\text { Pan et al., } 2010\end{array}$ \\
\hline Deciduous & $\begin{array}{l}2549 \\
4210,3220,3350 \\
2890.8\end{array}$ & 3244.0 & 25.8 & 83.7 & $\begin{array}{l}\text { Zhang et al., 2008b } \\
\text { Zhang et al., 2008a } \\
\text { Liu et al., } 2009\end{array}$ \\
\hline
\end{tabular}


of $\mathrm{Hg}$ through leaf litterfall is important for the transport of atmospheric $\mathrm{Hg}$ to soil in Chinese forests.

The urban forest is an important forest type and is closely related with the daily life of humans. However, studies on litterfall in urban forests are limited, thus it is necessary to conduct research on the role of litterfall on the $\mathrm{Hg}$ cycle of urban forests.

\section{Conclusions}

In Chinese suburban forests, the $\mathrm{Hg}$ concentrations and fluxes in leaf litter in evergreen broadleaf forests were higher than those in deciduous broadleaf forests. The $\mathrm{Hg}$ concentrations in $\mathrm{O}$ horizons were higher than those in A horizons, and the $\mathrm{Hg}$ concentration in the $\mathrm{O}$ horizon at $\mathrm{CBM}$ was the highest among these sites. This data indicated that leaf litterfall is important for the transport of atmospheric $\mathrm{Hg}$ to soil in both evergreen and deciduous broadleaf forests.

The $\mathrm{Hg}$ concentrations in leaf litter at urban sites were higher than those at suburban sites for each plant. The $\mathrm{Hg}$ concentrations in surface soil in Beijing increased from suburban to urban areas, with the highest value at the center of Beijing. It therefore appears that the distribution of $\mathrm{Hg}$ in urban forests is strongly influenced by anthropogenic activities.

\section{Acknowledgments}

This work was supported by the National Natural Science Foundation of China (No. 40803033, 41073092). The authors would like to thank Yujing Mu, Yi Zhang, Zhanyi Wang and Bingwen Li from Research Center for EcoEnvironmental Sciences, Chinese Academy of Sciences for their suggestions and help in sample collection. The anonymous reviewers are acknowledged for their valuable comments.

\section{References}

Barghigiani C, Ristori T, Bauleo R, 1991. Pinus as an atmospheric Hg biomonitor. Environmental Technology, 12(12): 11751181.

Chen A L, Lin S Z, Chen S P, Chen Y Z, 2006. Comparison on litterfall character of Phoebe bournei and Cunninghamia lanceolata plantation in the field of successive planting Cunninghamia lanceolata. Journal of Fujian College of Forestry, 26(4): 289-293.

Chen X, Xia X H, Wu S, Wang F, Guo X J, 2010. Mercury in urban soils with various types of land use in Beijing, China. Environmental Pollution, 158(1): 48-54.

De Temmerman L, Claeys N, Roekens E, Guns M, 2007. Biomonitoring of airborne mercury with perennial ryegrass cultures. Environmental Pollution, 146(2): 458-462.

De Temmerman L, Waegeneers N, Claeys N, Roekens E, 2009. Comparison of concentrations of mercury in ambient air to its accumulation by leafy vegetables: An important step in terrestrial food chain analysis. Environmental Pollution, 157(4): 1337-1341.

Engle M A, Gustin M S, Zhang H, 2001. Quantifying natural source mercury emissions from the Ivanhoe Mining
District, north-central Nevada, USA. Atmospheric Environment, 35(23): 3987-3997.

Environmental Monitoring of China, 1994. The illustrated handbook of the background value of soil environment in the People's Republic of China. Chinese Environment Sciences Press, Beijing. 26-75.

Ericksen J A, Gustin M S, Schorran D E, Johnson D W, Lindberg S E, Coleman J S, 2003. Accumulation of atmospheric mercury in forest foliage. Atmospheric Environment, 37(12): 1613-1622.

Fan H B, Li Y Y, Su B Q, Lin D X, Liu C H, Jiang Z K, 2006. Allocation pattern of biomass and productivity in the mixed uneven-aged stands of Masson's pine and hardwood species. Acta Ecologica Sinica, 26(8): 2463-2473.

Fostier A H, Cecon K, Forti M C, 2003. Urban influence on litterfall trace metals fluxes in the Atlantic Forest of São Paulo (Brazil). Journal de Physique IV (Proceeding), 107(1): 491-494.

Fu X W, Feng X B, Zhu W Z, Rothenberg S, Yao H, Zhang $\mathrm{H}, 2010$. Elevated atmospheric deposition and dynamics of mercury in a remote upland forest of southwestern China. Environmental Pollution, 158(6): 2324-2333.

Graydon J A, St Louis V L, Hintelmann H, Lindberg S E, Sandilands K A, Rudd J W M et al., 2008. Long-term wet and dry deposition of total and methyl mercury in the remote boreal ecoregion of Canada. Environmental Science and Technology, 42(22): 8345-8351.

Guan L L, Zhou G Y, Zhang D Q, Liu J X, Zhang Q M, 2004. Twenty years of litter fall dynamics in subtropical evergreen broad-leaved forests at the Dinghushan forest ecosystem research station. Acta Phytoecologica Sinica, 28(4): 449456.

Guo Z L, Zheng J P, Ma Y D, Li Q K, Yu G R, Han S J et al., 2006. Researches on litterfall decomposition rates and model simulating of main species in various forest vegetations of Changbai Mountains, China. Acta Ecologica Sinica, 26(4): 1037-1046.

Gustin M S, Lindberg S E, Austin K, Coolbaugh M, Vette A, Zhang H, 2000. Assessing the contribution of natural sources to regional atmospheric mercury budgets. Science of the Total Environment, 259(1-3): 61-71.

Gustin M S, Lindberg S E, Weisberg P J, 2008. An update on the natural sources and sinks of atmospheric mercury. Applied Geochemistry, 23(3): 482-493.

Hou Y, Wang B S, Zhang H D, Li M G, 1998. The litterfall of the south subtropical evergreen broad-leaved forest in Heishiding nature reserve. Ecologic Science, 17(2): 14-18.

Iverfeldt $\AA$, 1991. Mercury in forest canopy throughfall water and its relation to atmospheric deposition. Water, Air, and Soil Pollution, 56(1): 553-564.

Larssen T, de Wit H A, Wiker M, Halse K, 2008. Mercury budget of a small forested boreal catchment in southeast Norway. Science of the Total Environment, 404(2-3): 290-296.

Li X H, Cheng H X, Zhao C D, Xu X B, 2010. Mercury contamination in the topsoil and subsoil of urban areas of Beijing, China. Bulletin of Environmental Contamination and Toxicology, 85(2): 224-228.

Lin Y M, He J Y, Yang Z W, Liu C D, Lin P, Li Z J, 1999. The dynamics and production of litter falls of Castanopsis eyrei community in Wuyi Mountains. Journal of Xiamen University (Natural Science), 38(2): 280-286.

Lindberg S E, Jackson D R, Huckabee J W, Janzen S A, Levin M J, Lund J R, 1979. Atmospheric emission and plant uptake of mercury from agricultural soils near the Almaden 
Mercury Mine. Journal of Environmental Quality, 8(4): 572-578.

Lindberg S E, Porcella D, Prestbo E, Friedli H, Radke L, 2004. The problem with mercury: too many sources, not enough sinks. RMZ Materials and Geoenvironment, 52: 1172-1176.

Liu S L, Nadim F, Perkins C, Carley R J, Hoag G E, Lin Y H et al., 2002. Atmospheric mercury monitoring survey in Beijing, China. Chemosphere, 48(1): 97-107.

Liu Y, Han S J, Lin L, 2009. Dynamic changes in soil nutrients of four types of forests in Changbai Mountains during litter decomposition. Journal of Northeast Forestry University, 37(8): 28-30.

Manta D S, Angelone M, Bellanca A, Neri R, Sprovieri M, 2002. Heavy metals in urban soils: a case study from the city of Palermo (Sicily), Italy. Science of the Total Environment, 300(1-3): 229-243.

Mélières M A, Pourchet M, Charles-Dominique P, Gaucher P, 2003. Mercury in canopy leaves of French Guiana in remote areas. Science of the Total Environment, 311(1-3): 261-267.

Millhollen A G, Gustin M S, Obrist D, 2006. Foliar mercury accumulation and exchange for three tree species. Environmental Science and Technology, 40(19): 6001-6006.

Munthe J, Hultberg H, Iverfeldt A, 1995. Mechanisms of deposition of methylmercury and mercury to coniferous forests. Water, Air, and Soil Pollution, 80(1-4): 363-371.

National Standards of the People's Republic of China, 1995. Environmental quality standard for soils. GB15618-1995.

Nóvoa-Muñoz J C, Pontevedra-Pombal X, Martínez-Cortizas A, Gayoso E G R, 2008. Mercury accumulation in upland acid forest ecosystems nearby a coal-fired power-plant in Southwest Europe (Galicia, NW Spain). Science of the Total Environment, 394(2-3): 303-312.

Obrist D, 2007. Atmospheric mercury pollution due to losses of terrestrial carbon pools? Biogeochemistry, 85(2): 119-123.

Pan H, Huang S D, Hong W, Zhao K, Zhang Z H, 2010. Litterfalls amounts and seasonal dynamics of carbon returns in three Acacia plantations. Journal of Fujian College of Forestry, 30(2): 104-108.

Pirroni N, Costa P, Pacyna J M, Ferrara R, 2001. Mercury emissions to the atmosphere from natural and anthropogenic sources in the Mediterranean region. Atmospheric Environment, 35(17): 2997-3006.

Rea A W, Keeler G J, Scherbatskoy T, 1996. The deposition of mercury in throughfall and litterfall in the lake champlain watershed: A short-team study. Atmospheric Environment, 30(19): 3257-3263.

Rea A W, Lindberg S E, Scherbatskoy T, Keeler G J, 2002. Mercury accumulation in foliage over time in two northern mixed-hardwood forests. Water, Air, and Soil Pollution, 133(1-4): 49-67.

Rodrigues S, Pereira M E, Duarte A C, Ajmone-Marsan F, Davidson C M, Grčman H et al., 2006. Mercury in urban soils: A comparison of local spatial variability in six European cities. Science of the Total Environment, 368(2-3): 926-936.
Roulet M, Lucotte M, Farella N, Serique G, Coelho H, Souza Passos C J et al., 1999. Effects of recent human colonization on the presence of mercury in Amazonian ecosystems. Water, Air and Soil Pollution, 112(3-4): 297-313.

Sheehan K D, Fernandez I J, Kahl J S, Amirbahman A, 2006. Litterfall mercury in two forested watersheds at Acadia National Park, Maine, USA. Water, Air, and Soil Pollution, 170(1-4): 249-265.

Silva-Filho E V, Machado W, Oliveira R R, Sella S M, Lacerda L D, 2006. Mercury deposition through litterfall in an Atlantic Forest at Ilha Grande, Southeast Brazil. Chemosphere, 65(11): 2477-2484.

State Environment Protection Administration of China (SEPAC), 1990. The Background Levels of Element in soil in China. Chinese Environmental Science Press, Beijing.

St Louis V L, Rudd J W M, Kelly C A, Hall B D, Rolfus K R, Scott K J et al., 2001. Importance of the forest canopy to fluxes of methyl mercury and total mercury to boreal ecosystems. Environmental Science and Technology, 35(15): 3089-3098.

Wan Q, Feng X B, Lu J L, Zheng W, Song X J, Li P et al., 2009. Atmospheric mercury in Changbai Mountain area, northeastern China II. The distribution of reactive gaseous mercury and particulate mercury and mercury deposition fluxes. Environmental Research, 109(6): 721-727.

Wang S X, Liu M, Jiang J K, Hao J M, Wu Y, Street D G, 2006. Estimate the mercury emissions from nor-coal sources in China. Chinese Journal of Environmental Science, 27(12): 2401-2406.

Wang Z W, Zhang X S, Xiao J S, Ci Z J, Yu P Z, 2009. Mercury fluxes and pools in three subtropical forested catchments, southwest China. Environmental Pollution, 157(3): 801808.

Wei L M, Yu D L, Chen Z R, 2009. Study on the dynamic variation of litter falls in Maolan Karst forest. Journal of Nanjing Forestry University (Natural Science Edition), 33(3): 31-34.

$\mathrm{Wu} \mathrm{Z} \mathrm{X,} \mathrm{2006.} \mathrm{Amount,} \mathrm{component,} \mathrm{and} \mathrm{seasonal} \mathrm{pattern} \mathrm{of}$ litterfall in secondary evergreen broadleaved forest. Journal of Mountain Science, 24(2): 215-221.

Yang Y S, Xie J S, Chen Y X, He Z M, 2001. Amount, composition and seasonal dynamics of litterfall in mixed forest of Cunninghamia lanceolata and Tsoongiodendron odorum. Scientia Silvae Sinicae, 37(Suppl. 1): 30-34.

Zhang D L, Mao Z J, Zhu S Y, Zhou B, 2008a. Litter falls of 6 major forest stands in Maoershan Mountain of Heilongjiang Province. Bulletin of Botanical Research, 28(1): 104-108.

Zhang X M, Luo K L, Sun X Z, Tan J A, Lu Y L, 2006. Mercury in the topsoil and dust of Beijing city. Science of the Total Environment, 368(2-3): 713-722.

Zhang X P, Wang X P, Zhu B, Zong Z J, Peng C H, Fang J Y, 2008b. Litter fall production in relation to environmental factors in northeast China's forests. Journal of Plant Ecology, 32(5): 1031-1040. 